\title{
Radical Love: Teachings from the Islamic Mystical Tradition
}

Omid Safi, trans. and ed. New Haven: Yale University Press, 2018. 335 pages.

Collections of poems from the Islamic mystical tradition are not at all unusual on the American market. Yet most of these collections have been published by presses that specialize in spirituality, so it is quite remarkable to see this collection of poetry translated and edited by Omid Safi being published by Yale University Press. Safi is a Professor of Islamic Studies in the Department of Asian and Middle Eastern Studies at Duke University in North Carolina, and he is author of numerous books such as Progressive Muslims (2003), The Politics of Knowledge in Premodern Islam (2006) and Memories of Muhammad: Why the Prophet Matters (2009). Yet he is probably better known as a public intellectual through his blogs and columns. 
Radical Love is a beautiful book, both in its contents and in its appearance. Navid Kermani (Gott ist schön, Munich 2007) and others have taught us that beauty is not irrelevant to God and to right religion, since "God is beautiful and loves beauty" as a famous hadith says (translated by Safi, 22). This dovetails with the broader insight represented by Shahab Ahmed in his wide-ranging manifesto What is Islam? (Princeton, 2016) that categories such as love, desire, and beauty can no longer be marginalized as heterodox forms of Islam but should, instead, be considered as pertaining to the mainstream of post-classical Balkan-to-Bengal complex of Islam.

As the title of Safi's collection suggests, the path of radical love is the heart of Islam. This insight is shared not only by the mystical lovers in Islam, but also by the philosophical traditions of the illuminationists and the perennialists. In this respect, his approach matches with recent publications by Prince Ghazi bin Muhammad (Love in the Holy Quran, 2010) and Reza Shah-Kazemi (My Love Encompasses All, 2007). Differently from them, however, Safi combines poetical texts from the Quran (14 texts) and the hadith literature (22 texts) with later voices, such as Jalāl al-dīn Rūmì (55 texts), Atțār (25), Kharāqānī (12), 'Irāqī (11), Sa 'dī (9), al-Sulamī (9), Inayāt Khān (8), Abū Sa'īd (7), and many others. Omid Safi introduces these mystics on the last pages of his introduction (xli-1). On the pages before that, he introduces the choices that he made in translating these poems from their original texts: he "sought to provide a new English translation that is evocative, fresh, accurate, and poetic" (xxxvii). Avoiding literalist and universalist tendencies, Safi's translations are indeed evocative, poetical and sometimes shockingly fresh ("Love is the GPS," 128).

The collection itself is divided into four parts: God of Love, Path of Love, Lover and Beloved, and finally Beloved Community. Introducing the first part, Safi makes clear that love is not a sentiment or an emotion but "the very overflowing of God onto this realm" (1). This love shines forth from God and illuminates Prophet Muhammad and through him all the saints. The path of love is not only the human quest for God but also the awareness that God is seeking humanity as well, so that it becomes a "sensual and spiritual love affair of seeking and yearning" (71). The poetry in the third part is characterized by Safi as a "delicious dance of ambiguity" (151) in which love flows from God through humanity and back to God, so that the divine and humane qualities of the beloved are often addressed together. Finally, the part on the beloved community prevents us from thinking that this is an individual love affair. As Safi writes in his introduction, 
the Qur'anic dimension of love, mercy, and beauty includes the idea of social justice (xxxvi).

It makes no sense trying to give an idea of the beauty of this collection by quoting one or two poems. Tolle, lege: pick up the book and taste carefully.

Pim Valkenberg Ordinary Professor of Religion and Culture The Catholic University of America, Washington, DC 